\title{
Groundwater Contamination Prediction Using Finite Element Derived Geoelectric Parameters Constrained by Chemical Analysis around a Sewage Site, Southwestern Nigeria
}

\author{
Oyelowo G. Bayowa ${ }^{1}$, Dele E. Falebita ${ }^{2 *}$, Martin O. Olorunfemi ${ }^{2}$, Adekunle A. Adepelumi \\ ${ }^{1}$ Department of Earth Sciences, Ladoke Akintola University, Ogbomoso, Nigeria \\ ${ }^{2}$ Department of Geology, Obafemi Awolowo University, Ile-Ife, Nigeria \\ Email:"delefalebita@hotmail.com, oyebayowa@yahoo.com,mlorunfe@yahoo.co.uk
}

Received March 25, 2011; revised January 16, 2012; accepted February 28, 2012

\begin{abstract}
Vertical Electrical Sounding, the Finite Element Technique (FET) and chemical analysis of soil samples were used to map the pollution plume around two oxidation sewage ponds in Ile-Ife, Southwestern Nigeria. The elemental concentrations of the soil samples at $5 \mathrm{~m}$ depth around the sewage ponds were obtained using partial extraction of exchangeable metals ions of $\left(0.05 \mathrm{HCl}+0.025 \mathrm{~N} \mathrm{H}_{2} \mathrm{SO}_{4}\right)$ or $0.075 \mathrm{~N}$ acid mixture. The VES interpreted results delineated three to four geoelectric subsurface layers comprising topsoil, laterite, weathered layer and the fresh basement. The elemental concentration of $\mathrm{Cu}, \mathrm{Zn}, \mathrm{Pb}$ and $\mathrm{Cr}$ in the soil samples located at the periphery of the sewage ponds are much higher than those of the control sample point indicating pollution. The finite element generated isopach map of the overburden indicates easterly direction of groundwater flow and weathered layer isoresistivity map generated using the finite element technique identifies low resistivity zone characteristic of pollution zone in the eastern flank. The study concluded that the groundwater in the area around the sewage ponds may have been polluted.
\end{abstract}

Keywords: Contamination; Finite Element; Sewage; Groundwater; Nigeria

\section{Introduction}

Groundwater pollution resulting from waste disposal is a matter of worldwide concern. Sewage sludge which represents 10 percent of municipal waste production has every chance of contaminating the groundwater which is an important source of public water supply. The quality of groundwater is as important as its quantity [1] and for water to be used for domestic purposes, such as drinking; it must be free from undesirable impurities and contaminants which could infiltrate an aquifer in-situ. However, release of partially treated, or even untreated municipal wastes water and sewage sludge into continental marine ecosystems, groundwater and soil may cause environmentally and politically unacceptable problems. Toxic elements, such as cadmium (Cd), Silver (Ag), Lead (Pb), Tin ( $\mathrm{Sn})$ and Zinc (Zn) as well as higher elements such as Aluminium (Al), if present in sewage sludge above certain maximum concentration levels can affect biota at a water-soluble concentration of less than $1 \mathrm{ppm}$ (part per million) [1].

Health concerns about the possible impacts of two

${ }^{*}$ Corresponding author. oxidation sewage ponds site in Ile-Ife, southwestern $\mathrm{Ni}$ geria, on the groundwater system have led to the present research. Each of the ponds is about $185 \times 260 \mathrm{~m}$ in dimension and has been site for all sorts of chemicals, including human wastes for over forty-five years. The aim of this study is to assess the degree of contamination in the study area using Finite Element derived geoelectric parameters constrained by chemical analysis of soil samples in the vicinity of the ponds.

The specific objectives of the research are therefore, to study the sub-surface geologic/geoelectric sequence and structures that may control the sub-surface fluid migration, identify groundwater contaminants from the waste disposal site using their chemical characteristics, and recommend safe areas for maximum extraction of uncontaminated groundwater in the study area using the finite element predicted geoelectric parameters. The study will also emphasize the reliability of geophysical method in mapping pollution plumes [2-6].

\section{The Study Area}

The study area lies within Ile-Ife, Nigeria and is bounded 
by longitudes $4^{\circ} 30^{\prime} 39.4^{\prime \prime} \mathrm{E}-4^{\circ} 31^{\prime} 6.5^{\prime \prime} \mathrm{E}$ and latitudes $7^{\circ} 30^{\prime} 12.2^{\prime \prime} \mathrm{N}-7^{\circ} 30^{\prime} 44.8^{\prime \prime} \mathrm{N}$ (Figure 1). Ile-Ife area is located within the Ife-Ijesha Schist Belt, which is predominantly a migmatite gneiss-quartzite complex [7]. classified the rocks of Ife-Ilesha Schist Belt into the migmatite gneiss-quartzite complex as slightly migmatized to non-migmatized metasedimentary and metaigneous rocks, and member of older granite suite.

It is also within the tropical rain forest and has two distinct seasons (wet, April-October; and dry, NovemberMarch). The annual mean rainfall is about $1600 \mathrm{~mm}$. The diurnal range in temperature is not significant, but the daily temperature can reach $29^{\circ} \mathrm{C}$ and is seldom lower than $25^{\circ} \mathrm{C}$. Specifically, the study area is underlain by regional grey gneiss, granite gneiss, mica schist and a sequence of lateritic clay (aquitards), weathered basement and fractured/fresh bedrock.

The grey gneiss occurs in the pediment area and is the oldest recognizable rock within the migmatite-gneissquartzite complex. The granite gneiss occurs as intrusion while the slightly migmatized to non-migmatized metasedimentary and metaigneous rocks (mica schists) of the area belong lithologically to mafic-ultramafic rocks. The weathered and fractured basement constitute the main aquifer and are located within bedrock depressions that control the groundwater flow pattern [8].

\section{Methods of Study}

\subsection{Soil Chemical Analysis}

Chemical analysis was done on the soil samples around the sewage ponds to obtain preliminary assessment of the extent of pollution with respect to exchangeable heavy metals (Figure 2). Soil samples from thirteen points around the sewage ponds at about $5 \mathrm{~m}$ depth were obtained and analyzed for their $\mathrm{Cu}, \mathrm{Zn}, \mathrm{Pb}, \mathrm{Cd}$ and $\mathrm{Cr}$ con-

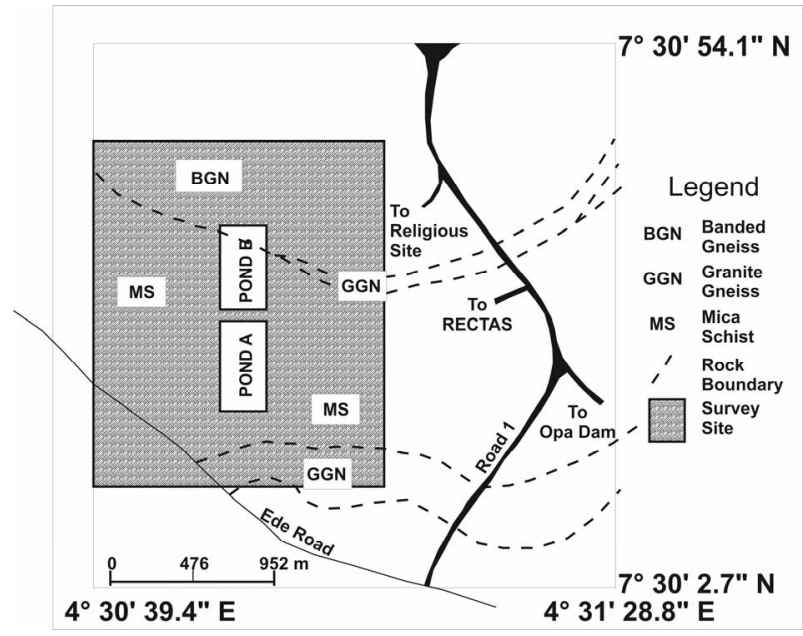

Figure 1. Generalized geologic map of the study area showing the oxidation ponds [9].

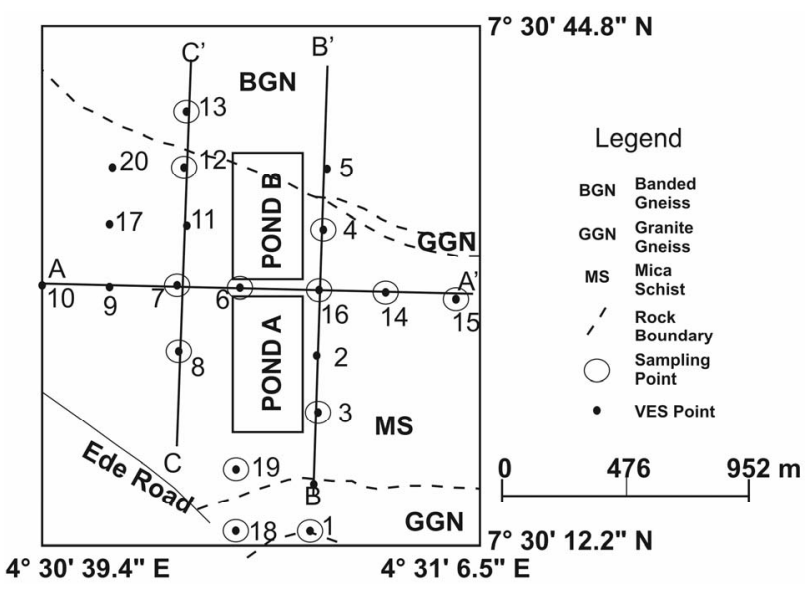

Figure 2. Map of the study site showing the chemical survey sampling points and the vertical electrical sounding (VES) stations.

centrations in ppm (part per million), using partial extraction of exchangeable metals ions of $(0.05 \mathrm{Hcl}+0.025$ $\mathrm{N} \mathrm{H}_{2} \mathrm{SO}_{4}$ ) or $0.075 \mathrm{~N}$ acid mixture [10-12]. These sampling points are represented in Figure 2 where sampling point 1 located at about $200 \mathrm{~m}$ away from the sewage was used as a control point. The results of the chemical analysis are presented in Table $\mathbf{1}$ and Figure 3.

\subsection{Geoelectric Survey}

The geoelectric parameters were determined using the Vertical Electrical Sounding (VES) technique. The technique involves the passage of electrical current (I), into the ground by means of current electrodes and the measurement of the potential difference $(\Delta V)$ between two potential electrodes. Although resistivity generally increases as porosity decreases, the electrical properties are controlled more by water quality than by the resistivities of the rock matrix [13]. What is actually measured either in the laboratory or field is the apparent resistivity given by:

$$
\rho_{a}=\frac{\Delta V}{I} \cdot G
$$

where $\rho_{a}$ is the apparent resistivity and $G$ is the geometric factor which is determined by the electrode configuration.

The Wenner electrode configuration with equal electrode spacing and geometric factor of $2 \pi a$, where $a$ is the inter-electrode spacing was used to acquire twenty vertical electric soundings (VES) with ABEM SAS 300C Resistivity. The resulting sounding curves were interpreted quantitatively and geoelectric sections were drawn along profiles $\mathrm{A}-\mathrm{A}^{1}, \mathrm{~B}-\mathrm{B}^{1}$ and $\mathrm{C}-\mathrm{C}^{1}$ (Figure 2) as a means of providing an insight into the subsurface sequence and the structural disposition. 
Table 1. Concentration of selected elements in the soil samples around the sewage ponds.

\begin{tabular}{cccccc}
\hline \multirow{2}{*}{$\begin{array}{c}\text { Sampling } \\
\text { Stations }\end{array}$} & \multicolumn{5}{c}{ Elements Concentration (ppm) } \\
\cline { 2 - 6 } & $\mathbf{C u}$ & $\mathbf{Z n}$ & $\mathbf{P b}$ & $\mathbf{C d}$ & $\mathbf{C r}$ \\
\hline 1 & 0.051 & 0.001 & 0.000 & 0.010 & 0.002 \\
3 & 0.193 & 0.410 & 0.000 & 0.002 & 0.000 \\
4 & 0.255 & 0.180 & 0.094 & 0.004 & 0.000 \\
6 & 0.206 & 0.370 & 0.027 & 0.030 & 0.012 \\
7 & 0.064 & 0.340 & 0.000 & 0.000 & 0.000 \\
8 & 0.138 & 0.240 & 0.203 & 0.030 & 0.004 \\
12 & 0.789 & 2.160 & 0.130 & 0.020 & 0.150 \\
13 & 0.305 & 0.530 & 0.091 & 0.020 & 0.560 \\
14 & 0.136 & 0.630 & 0.079 & 0.000 & 0.000 \\
15 & 0.078 & 0.420 & 0.098 & 0.003 & 0.016 \\
16 & 0.202 & 0.120 & 0.000 & 0.000 & 0.000 \\
18 & 0.053 & 0.047 & 0.000 & 0.000 & 0.000 \\
19 & 0.051 & 0.045 & 0.004 & 0.000 & 0.002 \\
\hline
\end{tabular}

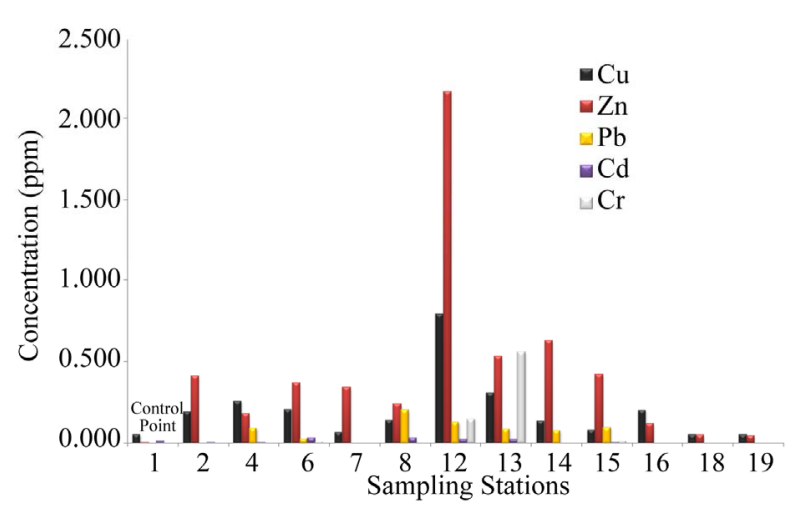

Figure 3. Plot of concentration of elements at Sampling Stations.

\subsection{Finite Element Prediction of Geoelectric Parameters}

The concept of Finite Element involves the visualization of a problem domain as an assemblage of building blockslike elements and nodal points-superimposed over the problem domain with the nodal points interconnected [14-18]. The finite element is implemented with a variety of element types but the commonly used element types are triangular, rectangular and polygonal. The triangular element approach was used in this study. The trial solution $t(x, y)$ is defined throughout the triangular element by linear interpolation of the nodal values $t_{i}, t_{j}$ and $t_{m}$. The nodes are designated by an index number $L$ and the nodal coordinates as $\left(x_{i}, y_{i}\right) ;\left(x_{j}, y_{j}\right)$ and $\left(x_{m}, y_{m}\right)$ respectively and are numbered $i, j$, and $m$ in counter clockwise order. The unknowns of the problem are the thicknesses and resistivities at the nodes:

$$
\begin{aligned}
& t_{i}=\left(x_{i}, y_{i}\right) \\
& t_{j}=\left(x_{j}, y_{j}\right) \\
& t_{m}=\left(x_{m}, y_{m}\right)
\end{aligned}
$$

It is expressed as a series summation; where each term is a product of a nodal thickness $\left(t_{L}\right)$ an associated nodal basis function $N_{L}(x, y)$.

$$
t(x, y)=\sum_{L=1}^{\mathrm{NNODE}} t_{L} N_{L}(x, y)
$$

where $L=$ the nodal number; $t=$ an approximate or trial solution and, NNODE = total number of nodes in the problem domain. The NNODE conditions are that the residuals of the governing equation weighted by each of the NNODE basis function be zero when integrated over the entire domain of the problem, i.e.,

$$
\iint_{D}\left(\frac{\delta^{2} t}{\delta x^{2}}+\frac{\delta^{2} t}{\delta y^{2}}\right) N_{L}(x, y) \delta x \delta y=0
$$

where $L=1,2, \cdots$, NNODE; $D=$ the integration is done over the entire problem domain. The residual is the quantity in parentheses.

The study area was broken into a $40 \times 40 \mathrm{~m}$ square grid network with the corners of the grid mostly constituting the test points. Each of the square grids was divided into triangular elements having three nodes-one at each corner. These nodes were the points within the problem domain at which the thicknesses and resistivities were computed. The problem domain consists of eighty nodal points and one hundred and twenty-six elements in all.

\section{Results and Discussion}

\subsection{Soil Chemistry}

Figure 3 shows histograms of the concentration levels of the analyzed elements for the different samples. Except for sample sites 18, 19 and 7 whose elemental concentration levels are close to that of the control site 1, other sample sites show concentration levels, most especially of $\mathrm{Cu}, \mathrm{Zn}, \mathrm{Pb}$ and $\mathrm{Cr}$, that are much higher than that of the control site 1 , indicating pollution presumably from the sewage pond. Majority of the sampling points $(3,4,6$ $8,12,13,14,15$ and 16) showing evidence of pollution bound the sewage ponds.

\subsection{Subsoil Geoelectrical Parameters Based on Geoelectric Sections}

Four distinct layers were identified from the interpretation of the geoelectric sections (Figure 4). These are the top soil, laterite, weathered layer and fresh basement respectively. Geoelectric Section A-A' relates VES stations $10,9,7,6,16,14$ and 15 along a W-E trending profile 


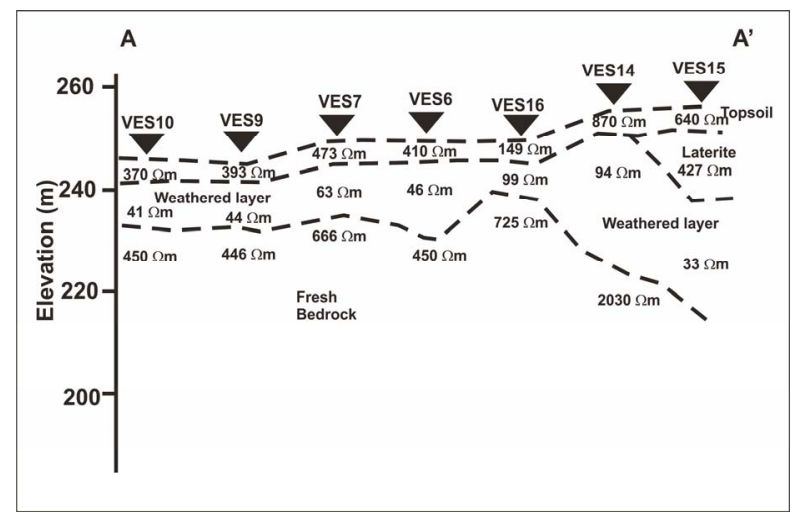

(a)

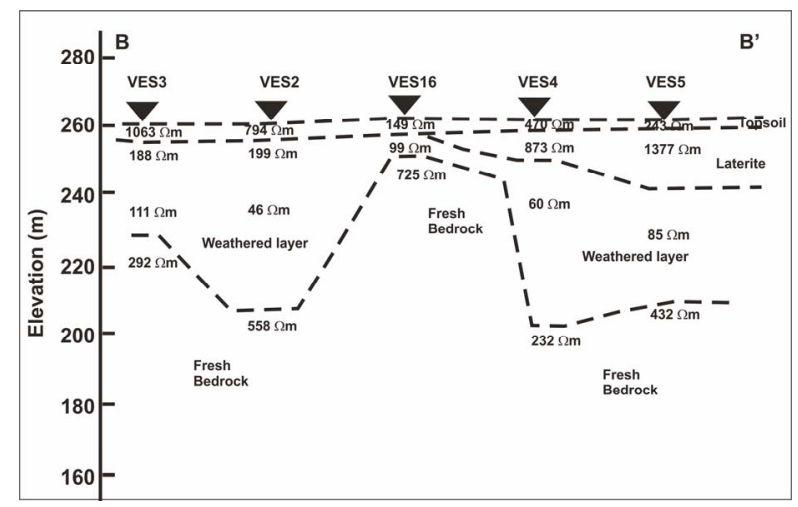

(b)

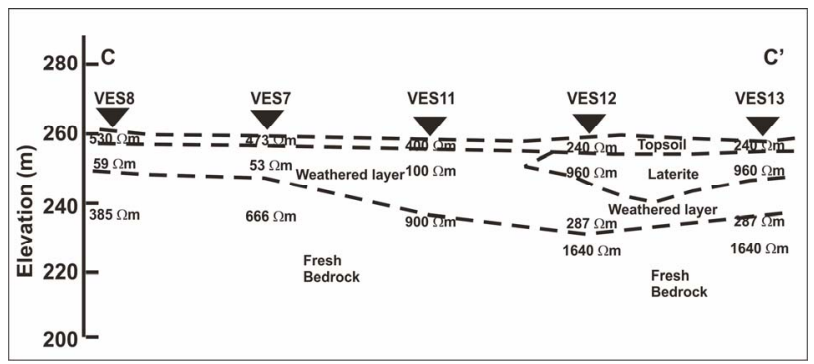

(c)

Figure 4. (a) Geoelectric section along profile A-A'; (b) Geoelectric section along profile B-B'; (c) Geoelectric section along profile C-C'.

(Figure 4(a)). The section spans a distance of about 280 $\mathrm{m}$ and delineates three layers. The first layer constitutes the topsoil with resistivity values ranging between 149 ohm-m and $870 \mathrm{ohm}-\mathrm{m}$. The layer thickness varies from 1.0 to $4.0 \mathrm{~m}$. A layer of laterite with resistivity value of 427 ohm-m underlies the topsoil beneath VES 15. The second layer which constitutes the weathered layer has resistivity values that range from $33 \mathrm{ohm}-\mathrm{m}$ to $99 \mathrm{ohm}-\mathrm{m}$, while the depth to the bottom of this layer varies from 14.0 to $17.5 \mathrm{~m}$. The third layer is the fresh basement layer with resistivity values that range between $446 \mathrm{ohm}-$ $\mathrm{m}$ and 2030 ohm-m.

Geoelectric Section B-B' relates VES 3, 2, 16, 4 and 5, along a south — north profile that stretches through a dis- tance of about $520 \mathrm{~m}$ (Figure 4(b)). Four distinct layers were identified beneath this section. The topsoil is characterized by layer resistivity value of 149 - 1063 ohm-m. The layer is $1.5-3.0 \mathrm{~m}$ thick. The top soil is underlain by laterite with resistivity range of between 873 and 1377 ohm-m in the vicinity of VES 4 and 5. The layer thickness varies from 4.3 to $10.7 \mathrm{~m}$. The third layer is a weathered basement characterized by layer resistivity values of between 46 and $111 \mathrm{ohm}-\mathrm{m}$. The depth to the bottom of the layer varies from 6.1 to $58.1 \mathrm{~m}$. The fourth layer is presumably the fresh basement characterized by layer resistivity values ranging from 232 to 725 ohm-m. The depth to the top of the layer ranges from 6.1 to 58.1 m.

The geoelectric section C-C' is along a S-N trending profile. It is about $520 \mathrm{~m}$ long (Figure 4(c)). This section relates VES 8, 7, 11, 12 and 13. It also shows four subsurface layers. The resistivity value of the first layer ranges between 240 and $530 \mathrm{ohm}-\mathrm{m}$. The layer thickness varies from 1.0 to $3.0 \mathrm{~m}$. This is underlain by laterite with resistivity values that range between 960 and 1440 ohm-m beneath VES 12 and 13. The third layer is the weathered basement with layer resistivity values of between 53 and 287 ohm-m. The layer thickness varies from 10 to $25 \mathrm{~m}$. The fourth layer constitutes the fresh basement characterized by layer resistivity values that range from 385 to $1640 \mathrm{ohm}-\mathrm{m}$. The depth to top of this layer varies from 26.0 to $48.6 \mathrm{~m}$.

\subsection{Finite Element Derived Isopach Map of the Overburden}

The Finite element isopach map (Figure 5) of the overburden shows the combined thickness of the topsoil, laterite and the weathered basement derived from the quantitative interpretation of the VES data and the finite element predicted thicknesses. The map shows that the thickness varies from less than $6 \mathrm{~m}$ in the western part to over $50 \mathrm{~m}$ in the eastern part indicating an easternly groundwater flow.

\subsection{Finite Element Derived Isoresistivity Map of the Weathered Layer}

The Isoresistivity map of the weathered layer (Figure 6) encompasses both the finite element derived resistivity values of the weathered layer and the vertical electrical sounding derived. The weathered layer resistivity varies from less than $50 \mathrm{ohm}-\mathrm{m}$ to greater than $550 \mathrm{ohm}-\mathrm{m}$. The low resistivity zone $(<60 \mathrm{ohm}-\mathrm{m})$ is suspected to be due to pollution by the sewage effluent [18]. The suspected polluted zone is elongated toward the east and in the direction of the groundwater flow. The pollution plume has a width extent of over $700 \mathrm{~m}$ and elongation of over 1 $\mathrm{km}$. 


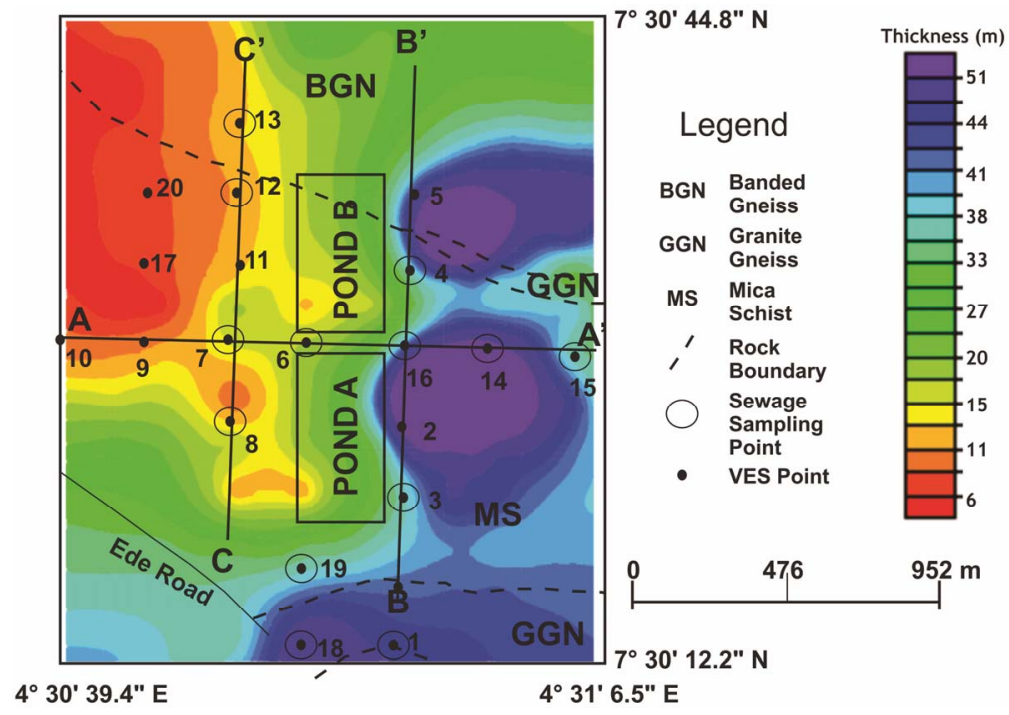

Figure 5. Finite element derived isopach map of the overburden.

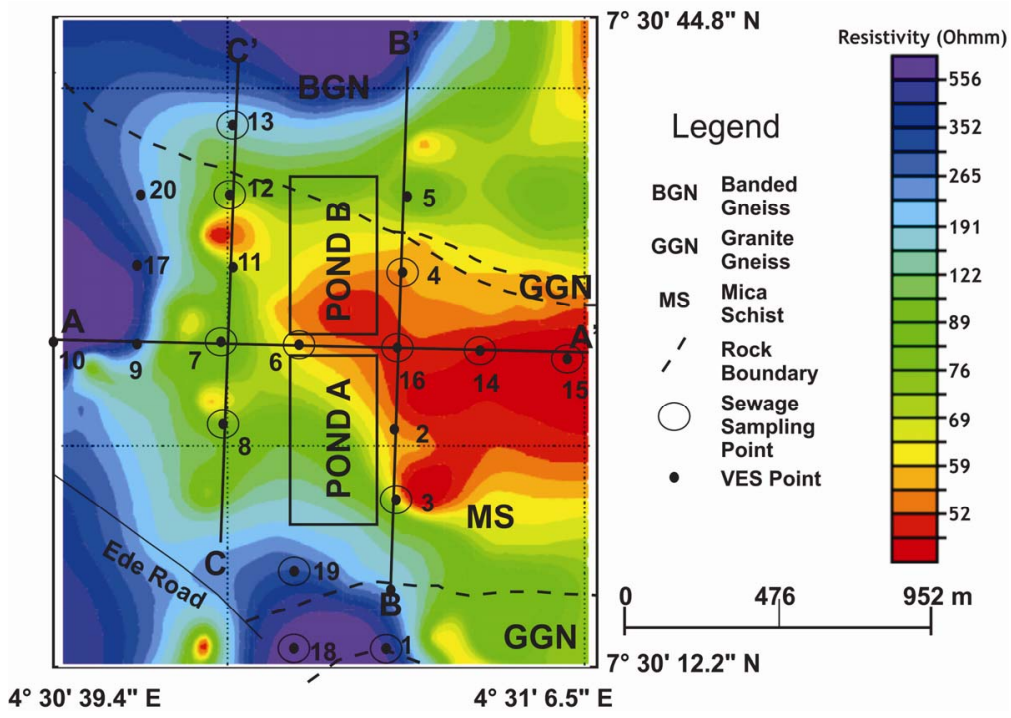

Figure 6. Finite element derived isoresistivity map of the weathered layer.

\section{Conclusion}

The Vertical Electrical Sounding, the Finite Element Technique (FET) and chemical analysis of soil samples have been used to map the pollution plume around two oxidation sewage ponds in Ile-Ife, Southwestern Nigeria. High elemental concentrations of $\mathrm{Cu}, \mathrm{Zn}, \mathrm{Pb}$ and $\mathrm{Cr}$ in the soil samples at $5 \mathrm{~m}$ depth around the sewage ponds indicate pollution. The finite element derived geoelectric parameters indicate that the pollution plume is elongated easterly in the direction of groundwater flow.

\section{REFERENCES}

[1] D. K. Todd, "Groundwater Hydrology," Reprints Edition, John Wiley and Sons Inc., New York, 1959, p. 336.
[2] J. S. Donaldson, "Electrical Methods of Detecting Contaminated Groundwater at the Stringfellow Waste Disposal Site, Riverside Country, California," Environmental Geology and Water Sciences, Vol. 6, No. 1, 1984, pp. 11-20. doi:10.1007/BF02525565

[3] N. S. Subba Rao, V. V. S. Gurunadha Rao and C. P. Gupta, "Groundwater Pollution Due to Discharge of Industrial Effluents in Ven-Katapura Area, Visakhapatnam, Andhra Pradesh, India," Environmental Geology, Vol. 33, No. 4, 1997, pp. 289-294. doi:10.1007/s002540050248

[4] W. B. Nixon and R. J. Murphy, "Waste Site Hazard Assessment: A Taxonomy of Current Methods and Criteria," Environmental Engineering and Policy, Vol. 1, 1998, pp. 59-74. doi:10.1007/s100220050006

[5] A. Adepelumi, B. Ako and T. Ajayi, "Groundwater Contamination in the Basement-Complex Area of Ile-Ife, 
Southwestern Nigeria: A Case Study Using the Electrical-Resistivity Geophysical Method," Hydrogeology Journal, Vol. 9, No. 6, 2001, pp. 611-622. doi:10.1007/s10040-001-0160-X

[6] A. A. Adepelumi, B. D. Ako, O. Afolabi and J. B. Arubayi, "Delineation of Contamination Plume around Oxidation Sewage-Ponds in Southwestern Nigeria," Environmental Geology, Vol. 48, No. 8, 2005, pp. 1137-1146. doi:10.1007/s00254-005-0056-5

[7] M. A. Rahaman and O. O. Ocan, "On Relationship in the Precambrian Migmatite Gneiss of Nigeria," Journal of Mining and Geology, Vol. 15, 1978, pp. 23-30.

[8] E. T. Okhue and M. O. Olorunfemi, "Electrical Resistivity Investigation of a Typical Basement Complex Area," Journal of Mining and Geology, Vol. 2, 1992, pp. 63-68.

[9] P. A. Oluwande, "Cheap Sewage Disposal in Developing countries," Ibadan University Press, Ibadan, 1978, pp. 46-49.

[10] P. Munsiri, C. E. Boyd and B. J. Hajek, "Physical and Chemical Characteristics of Bottom Soil Profiles in Ponds at Auburn, Alabama, and a Proposed Method for Describing Pond Soil Horizons," Journal of the World Aquaculture Society, Vol. 26, No. 4, 1995, pp. 346-377. doi:10.1111/j.1749-7345.1995.tb00831.x

[11] C. E. Boyd and P. Munsiri, "Phosphorus Adsorption Capacity and Availability of Added Phosphorus in Soils from Aquaculture Areas in Thailand," Journal of the
World Aquaculture Society, Vol. 27, 1996, pp. 160-167. doi:10.1111/j.1749-7345.1996.tb00265.x

[12] C. E. Boyd, C. W. Wood, T. Thunjai and S. Sonnenholzner, "Pond Soil Characteristics and Dynamics of Soil Organic Matter and Nutrients," In: K. McElwee, D. Burke, M. Niles, X. Cummings and H. Egna, Eds., 17th Annual Technical Report. Pond Dynamics/Aquaculture CRSP, Oregon State University, Corvallis, 2000, pp. 1-8.

[13] P. Keary and M. Brooks, "An Introduction to Geophysical Exploration,” Blackwell, Oxford, 1984.

[14] R. Fenner, "Finite Element Method for Engineers," Macmillan Press Ltd., London, 1975, pp. 31-44.

[15] A. A. Agbede, "The Finite Elements Analysis of the Opa River Dam," Unpublished MSc Thesis, Obafemi Awolowo University, Ile-Ife, 1981, p. 32.

[16] H. F. Wang and M. P. Anderson, "Groundwater Modelling with Finite Difference and Finite Element Methods," Elsevier Publishing, Amsterdam, 1982, pp. 1-137.

[17] A. A. Adepelumi, M. O. Olorunfemi, D. E. Falebita and G. O. Bayowa, "Structural Mapping of Coastal Plain Sands Using Engineering Geophysical Technique: Lagos, Nigeria Case Study," Natural Science, Vol. 1, No. 1, 2009, pp. 2-9. doi:10.4236/ns.2009.11002

[18] D. W. Urish, "The Practical Application of Surface Electrical Resistivity to Detection of Ground-Water Pollution," Groundwater, Vol. 21, 2006, pp. 144-152. doi:10.1111/j.1745-6584.1983.tb00711.x 